something in the soil has an effect on the roots, which have a characteristic stunted appearance and cover a much smaller volume than normal roots.

The consequences of the replant problem have now been convincingly demonstrated by a series of experiments at the East Malling Research Station. Apple trees planted in an old apple orchard are small and poorly developed compared with similar trees planted after treating the soil with chloropicrin. This substance obviously gets rid of whatever it is that stunts growth, but it is dangerous, expensive and unpleasant to handle. Acidifying the soil is also effective but is much more expensive. Research is continuing at the root laboratory of the station to identify the cause-organism or substance. Although nematodes and viruses have been more or less ruled out, bacteria may be the culprits. In any event, the work has produced interesting new results on the growth of fruit tree roots and on the habits of the nematodes which prey on them.

\section{Weizmann Institute}

True Annual Report of the Weizmann Institute shows that the establishment of the institute at the end of 1965 consisted of 300 scientists and engineers. At the same time there were 89 visiting scientists in residence. During the year $£ 952,000$ was contributed to the institute's budget by agencies, foundations and other organizations in Israel and elsewhere, and supported roughly a quarter of the work being done.

\section{Index to Food Safety}

Tire vigour of the Food and Drug Administration has given the United States a fine reputation on food safety. The National Academy of Sciences has now done its bit to help by the publication of a comprehensive definition of standards of identity and purity for some 500 food additives now in use in the United States (Food Chemicals Codex, National Academy of Sciences-National Research Council, \$25.00). The volume is the result of five years of work by a Com. mittee on Specifications under Dr. Henry Fischbach, of the Food and Drug Administration. Draft spccifications prepared by the committee, and with the help of an advisory panel under Mr. R. B. Smith, President of the Medical College of Virginia, were criticized by interested parties in industry, research and government before being cast in final form. The principal value of the new publication will be the way in which it will enable food manufacturers in the United States to interpret and abide by the necessarily laconic regulations which embody the ways in which the U.S. Government has sought to control the use in American foodstuffs of the 575 chemicals considered to be safe.

\section{Professor E. A. Guggenheim}

The University of Reading is about to lose Professor E. A. Guggenheim, who retires on September 30. He has been head of the Department of Chemistry at Reading since 1946, and during this period has made his principal contributions to thermodynamics and statistical mechanics. During the same period he has built up a vigorous School of Physical Chemistry at the University. He will be succeeded as head of the Department by Professor G. W. A. Fowles, at present Professor of Inorganic Chemistry. Guggenheim has been nominated Emeritus Professor.
University News:

London

Dr. J. M. Hinton, first assistant in the Academic Depart. ment of Psychiatry in the Middlesex Hospital Medical School, has been appointed to the chair of psychiatry tenable at that school.

\section{Appointments}

Mr. W. J. Bray has been appointed director of research at the Post Office in succession to Dr. G. H. Metson, who retired in August.

\section{Announcements}

The United States National Academy of Sciences and the National Academy of Engineering has announced the appointment of John C. Kohl as executive secretary of the Division of Engineering of the National Research Council, effective September 15. The NRC is the operating agency for both Academies.

Mr. Kohl, a civil engineer with broad experience in the field of urban transportation, became executive viceprosident of the American Transit Association in March this year, after serving since 1961 as assistant administrator (transportation) of the Federal Housing and Home Finance Agency, responsible for its urban transportation programme including capital grants and transit demonstration projects authorized under the Urban Mass Transportation Act of 1964. He held that position on leave from the University of Michigan, where he was Professor of Civil Enginecring and Director of the Transportation Institute.

Mr. Kohl succeeds Louis Jordan, who is retiring as executive secretary of the division after 24 years as a member of the NRC staff. Mr. Jordan will continue to serve the division as special consultant to its chairman, John A. Hutcheson.

The Division of Engineering, one of eight NRC Divisions, includes in its membership representativos of more than 20 national professional organizations as well as membersat-large drawn from various engineering specialties; more than 1,200 engineers and scientists from tho acadomic community, industry and government participate in the Division's activities.

Awards for postdoctorate research on the biochemical and physiological mochanisms of fortility and early stages of reproduction in various forms of life are being offered by the Lalor Foundation, Delaware, U.S.A., for tenuro during 1967. They are open to scientists of all nationalities and may range up to $\$ 8,000$ per year depending on the scope and duration of the projects approved. Preference will be given to younger members of university and college faculty and staff with an upper age limit of 41 years. The work may be carried on at the applicant's own institution or elsewhere. The foundation will also grant postgraduate summer or short-term research awards at the Marine Biological Laboratory at Woods Hole, Massachusetts. These awards will normally not exceed $\$ 1,200$ for a single man or a woman, $\$ 1,400$ for a married man working at his home institution, and $\$ 1,600$ for a married man with principal programmo at another institution. Requests for information and for application forms should be directed to the Lalor Foundation, 4400 Lancaster Pike, Wilmington, Delaware 19805.

Tre International Association for Plant Physiology has prepared an International Directory of Plant Physiologists associated with its fifteen constituent national organizations. Copies may be purchasod for $\$ 1.00$ from the secretary-trcasurer, Prof. Arthur W. Galston, Department of Biology, Yale University, New Haven, Connecticut.

THE journal Respiration Physiology (Nature, 211, 901; $1966)$ is published by the North-Holland Publishing Company. 